\title{
Synthesis, Characterization and Biological Evaluation of Some Pyrrole Derivatives as Potential Antimicrobial Agents
}

\section{Safiya R. Shaikh"1, Hanmant S. Mali², Shubhangi S. Thorat ${ }^{3}$, Vishwajit D. Dhaygude ${ }^{4}$, Muskan M. Bhaldarakar ${ }^{5}$,} Akshay R. Yadav 6

1,3,5,6Department of Pharmaceutical Chemistry, Rajarambapu College of Pharmacy, Kasegaon, Dist-Sangli, Maharashtra, India-415404

${ }^{2}$ Department of Pharmaceutics, Rajarambapu College of Pharmacy, Kasegaon, Dist-Sangli, Maharashtra, India415404

${ }^{4}$ Department of Quality Assurance, Tatyasaheb Kore College of Pharmacy, Warananagar, Dist-Kolhapur, Maharashtra, India

Corresponding author E-mail: safiyashaikh1330@gmail.com

\begin{abstract}
Article Info

Volume8, Issue 3

Page Number: 757-770

Publication Issue

May-June-2021

\section{Article History}

Accepted : 12June2021

Published :20June2021

Novel series of pyrrole derivatives were synthesized with an approach to develop more potent and less side effects having antimicrobial activity. An efficient synthesis of different novel 2-methyl-7(4-nitrophenyl)-5,6-diphenyl3,7-dihydro-4H-pyrrolo-[2,3-d]pyridine-4-one derivatives by the Paal-knorr Condensation. Benzoin with primary aromatic amines refluxing in ethanol resulted the formation of $\alpha$-aminoketone intermediates, which were condensed, without isolation, with malononitrile to yield the various 2-amino4,5-diphenyl-1-substituted-1H-pyrrole-3-carbonitriles (Ia-e). Pyrrole (Ia-e) further reacted with acid such as acetic acid to yield compound (IIa-e). The synthesized compounds were confirmed through spectral characterization using IR, Mass and 1H NMR. Result indicated that these compounds showed promising antimicrobial activity by comparing to standard drugs.
\end{abstract}

Keywords: Pyrrole derivatives, Characterization, Biological Evaluation, Antimicrobial activity.

\section{INTRODUCTION}

Pharmaceutical chemistry is a scientific discipline at the intersection of chemistry and pharmacy involved with designing and developing pharmaceutical drugs. ${ }^{1}$ These are chemical compounds that may be used in diagnosis, treatment, cure and mitigation of disease or other abnormal conditions. Pyrrole ${ }^{2}$ derivatives are display diverse biological activity. In the preparation of pyrrole derivative many disadvantages including harsh reaction condition and poor yields by applying Paal Knorr reaction. Pyrrole derivatives are considerable attention of synthetic importance and extensively used in drug discovery and 
pharmacological activity such as antimicrobial ${ }^{3-9}$. Microwave heating is the best method due to the microwave couple directly with the molecule that are present in the mixture, leading to fast rise in temperature, faster reaction and cleaner chemistry ${ }^{10-19}$. The microwave is also called as green chemistry because it does not produce any hazardous material like gas fumes or heating using external energy source $^{20-32}$. Microwave uses electromagnetic radiation that passes through material and causes oscillation of molecule which produces heat. Microwave heating produces heat in entire material in the same rate and the same time at a high speed and at a high rate of reaction ${ }^{35-49}$. Microwave assisted synthesis has become an important tool to the medicinal chemist for rapid organic synthesis ${ }^{50-68}$. Application of microwave technology in organic synthesis has some of the major advantages like spectacular decrease in reaction in reaction time, improved conversions, clean product formation and wide scope for the development of the new reaction conditions ${ }^{68-82}$. Due to its ability to couple directly with the reaction molecule and by passing thermal conductivity leading to a rapid rise in the temperature, microwave irradiation has been used to improve many organic synthesis ${ }^{83-98}$. Recrystallization can affect physical and chemical stability, apparent solubility, dissolution, bioavailability and bioequivalence and drug product manufacturability, which require special attention during product development as it affects drug product quality, protection and effectiveness ${ }^{99-118}$. It describes to exsist in two or more crystalline phases which have different arrangement of molecules in solid state with different arrangements or conformations of constituents in crystal lattices ${ }^{119-124}$.

\section{MATERIALS AND METHODS}

All chemicals and solvents were procured from commercial sources, purified and dried using standard procedures from literature whenever required the regents were purchased from S.D fine, Research laboratory, mumbai and marck laboratory, mumbai. The melting points of synthesized compound were determined by open capillary tube method and are uncorrected. Thin layer chromatography was used confirmation of reaction and the purity of the intermediate and the final compounds by applying a single spot on TLC plate (silica gel G) using various solvents such as butanol, chloroform, water system. TLC plates were visualized under iodine chamber. IR spectra were recorded on FTIR, 1H NMR spectra were performed in DMSO solution using Bruker 300 $\mathrm{MHz}$ and their chemical shift are reported in $\delta$ unit with respect to TMS as internal standard. Mass spectra were recorded on Pe sciex (model no. API 2000) software analyst 1.4.2 mode: Q1MS Q1/AUTO INJECTION from diya lab, airoli, mumbai.

General method for the Synthesis of 2-amino-4,5diphenyl-1-substituted-1H-pyrrole- 3 carbonitrile [Iae]

A mixture of benzoin (2.12 g, $0.01 \mathrm{~mol})$, amine like [a] p-nitroaniline (1.83 g, $0.01 \mathrm{~mol})$, [b]4-bromoaniline (1.72 g, $0.01 \mathrm{~mol})$, [c] 4-ethylaniline (1.28 g, 0.01mol), [d] 2,4dinitroaniline $(2.02 \mathrm{~g}, 0.01 \mathrm{~mol})$, and [e] N,N dimethyl(1.45 g, 0.01mol) and conc. $\mathrm{HCl}$ (6-8 drops) in ethanol $(40 \mathrm{ml})$ was irradiated under microwave for $10 \mathrm{~min}$. and cooled. Malononitrile (1.66 mg, 0.01 mol) was added, followed by a catalytic amount (1.5 $\mathrm{ml}$ ) of pyridine portion wise and refluxed for $3 \mathrm{hr}$. till solid formed. The solid residue was recrystallized from methanol to give compounds 2-amino-4,5diphenyl-1-substituted -1H-pyrrole-3 carbonitrile [Ia-e]

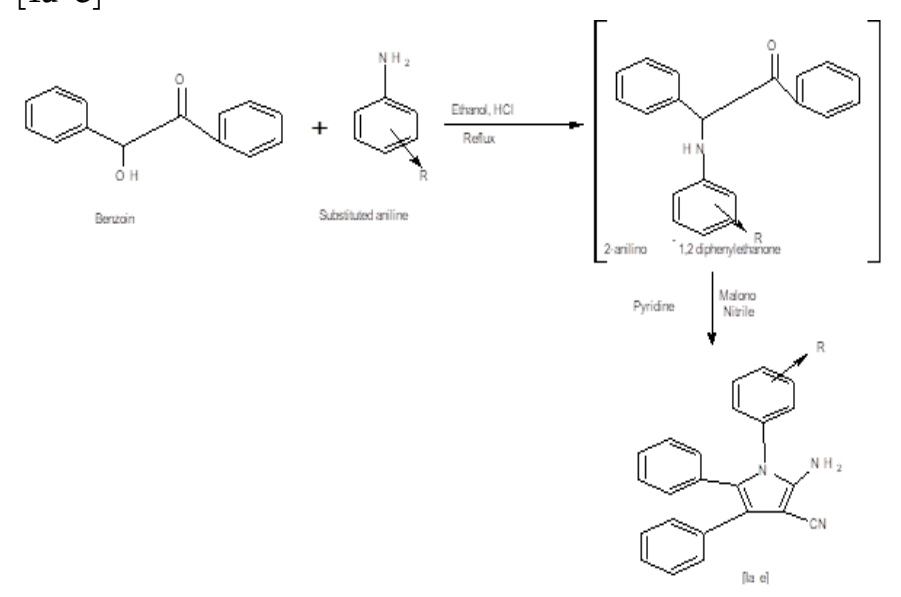


General method for the Synthesis of 7-(substituted aniline)-5,6 diphenyl-3,7dihydro-4H-pyrrolo[2,3-d] pyrimidine-4-one. [IIFa-e] ${ }^{8}$

7-(substituted aniline)-5,6 diphenyl-3,7dihydro-4Hpyrrolo[2,3-d]pyrimidine-4-one[IIFa-e] was synthesized by taking appropriate amount of Synthesis of 2-amino-4,5-diphenyl-1- substituted-1Hpyrrole-3-carbonitrile [Ia-e] in formic acid $(40 \mathrm{ml})$ was irradiated in microwave for $15 \mathrm{~min}$. cooled, poured onto ice-water to give precipitate. Which were filtered off, dried andrecrystallized from methanol gives the compounds7-(substituted aniline)5,6 diphenyl-3,7dihydro-4H-pyrrolo[2,3d]pyrimidine-4-one [IIFa-e].
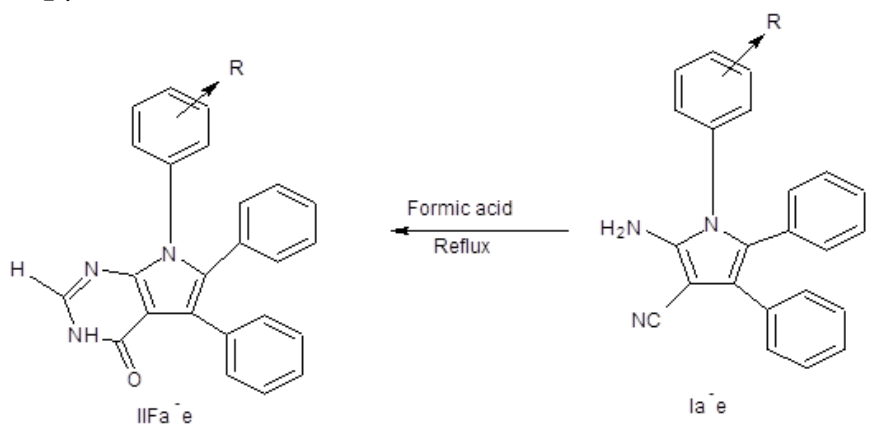

\section{Analytical Data of 2-methyl-7(4-nitrophenyl)-5,6 diphenyl-3,7 dihydro-4H-pyrrolo [2,3-d]pyridine-4- one derivatives}

The structural characterization of the synthesized compounds was done by the interpretation of IR, $1 \mathrm{H}$ NMR and MASS spectra. The entire compound showed satisfactory IR, 1H NMR and MASS data.

Table 1: Analytical Data of pyrrole derivatives

\begin{tabular}{|c|c|c|c|}
\hline $\begin{array}{l}\text { Compound } \\
\text { code }\end{array}$ & $\begin{array}{l}\text { Mass } \\
\mathrm{m} / \mathrm{z}\end{array}$ & $\operatorname{IR}\left(\mathrm{cm}^{-1}\right)$ & ${ }^{1} \mathrm{HNMR}$ (ppm) \\
\hline IIFa & 367 & $\begin{array}{lr}3360 & (\mathrm{NH}), \\
3020 \quad \text { (Aro } & \mathrm{C}- \\
\mathrm{H}), 2350 & \text { Aryl } \\
\left(\mathrm{NO}_{2}\right), & 1790 \\
(\mathrm{C}=\mathrm{O}), & 1670 \\
(\mathrm{C}=\mathrm{N}), & 1440 \\
(\mathrm{C}-\mathrm{N}) & \end{array}$ & $\begin{array}{l}7.2-7.9(\mathrm{~m}, \mathrm{Ar}- \\
14 \mathrm{H}, \quad 4,5 \\
\text { Diphenyl } \\
\text { ring), } 5.9 \quad(\mathrm{~s}, \\
1 \mathrm{H} \text { of } \mathrm{NH}), 4.6 \\
\text { (s, 1H C-H of } \\
\text { pyridine) }\end{array}$ \\
\hline IIFb & 404 & 3430 & $7.4-7.8(\mathrm{~m}, \mathrm{Ar}$ \\
\hline
\end{tabular}

\begin{tabular}{|c|c|c|c|}
\hline & & $\begin{array}{lr}3050 & \text { (Aro C- } \\
\mathrm{H}), & 1710 \\
(\mathrm{C}=\mathrm{O}), & 1610 \\
(\mathrm{C}=\mathrm{N}), & 1450 \\
(\mathrm{C}-\mathrm{N}), & 470 \\
\text { (Aryl Br) } & \end{array}$ & $\begin{array}{l}14 \mathrm{H}, \quad 4,5 \\
\text { Diphenyl } \\
\text { ring), } 5.9 \quad(\mathrm{~s}, \\
1 \mathrm{H} \text { of } \mathrm{NH})\end{array}$ \\
\hline IIFC & 390 & 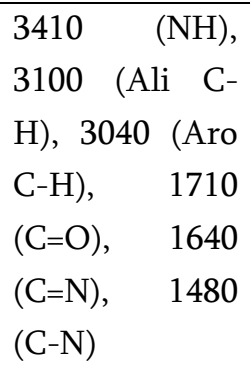 & $\begin{array}{l}7.5-7.7(\mathrm{~m}, \text { Ar- } \\
14 \mathrm{H}, \\
\text { Diphenyl } \\
\text { ring), } 5.9 \quad(\mathrm{~s}, 5 \\
1 \mathrm{H} \text { of } \mathrm{NH}), 4.6 \\
(\mathrm{~s}, 1 \mathrm{H} \mathrm{C}-\mathrm{H} \text { of } \\
\text { pyridine) }\end{array}$ \\
\hline IIFd & 386 & 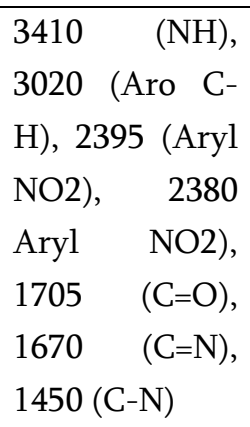 & $\begin{array}{l}7.2-7.8(\mathrm{~m}, \mathrm{Ar}- \\
14 \mathrm{H}, \\
\text { Diphenyl } \\
\text { ring), } 5.9 \quad(\mathrm{~s}, \\
1 \mathrm{H} \text { of } \mathrm{NH}), 4.6 \\
(\mathrm{~s}, 1 \mathrm{H} \mathrm{C}-\mathrm{H} \text { of } \\
\text { pyridine) }\end{array}$ \\
\hline IIFe & 398 & $\begin{array}{lr}3090 & \text { (Ali CH), } \\
3040 & \text { (Aro C- } \\
\mathrm{H}), & 1710 \\
(\mathrm{C}=\mathrm{O}), & 1610 \\
(\mathrm{C}=\mathrm{N}), & 11450 \\
(\mathrm{C}-\mathrm{N}) & \end{array}$ & 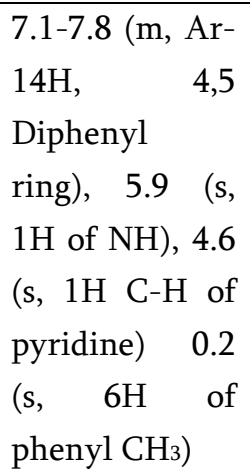 \\
\hline
\end{tabular}

\section{Biological Evaluation:}

\section{In vitro antimicrobial activity}

The compounds IIFa-ewere evaluated for their in vitro antimicrobial activity against E. coli, S. aureus, B. substilis and S. typhi by disk diffusion method was performed using Mac Conkeys agar and Nutrient agar medium. Each compound was tested at a concentration at $100 \mu \mathrm{g} / \mathrm{ml}$ in DMSO. The zone of inhibition was measured after $24 \mathrm{hr}$ incubation at 37 ${ }^{\circ} \mathrm{C}$.

\section{RESULTS AND DISCUSSION}


Microwave-assisted synthesis has advantages over conventional technology: it is more energy efficient and it can lead to improved isolated yields of products with green synthesis. The synthesized compounds were characterized by spectral analysis and all the compounds were in full harmony with the proposed structures.

The physiochemical result of compounds IIFa-e were shown as

Table 2: Physicochemical data of compounds (Ia-e)

\begin{tabular}{|c|c|c|c|c|c|}
\hline $\begin{array}{c}\text { Comp. } \\
\text { no. }\end{array}$ & $\mathbf{R}$ & $\begin{array}{c}\text { Molecular } \\
\text { Formula }\end{array}$ & M.P ${ }^{\circ} \mathrm{C}$ & $\begin{array}{c}\% \\
\text { Yield }\end{array}$ & $\begin{array}{c}\mathbf{R}_{\mathbf{f}} \\
\text { Value }\end{array}$ \\
\hline $\mathrm{Ia}$ & $\mathrm{P}-\mathrm{NO}_{2}$ & $\mathrm{C}_{13} \mathrm{H}_{16} \mathrm{~N}_{4} \mathrm{O}_{2}$ & $142-144$ & 79.2 & 0.81 \\
\hline $\mathrm{Ib}$ & $\mathrm{P}-\mathrm{Br}$ & $\mathrm{C}_{13} \mathrm{H}_{16} \mathrm{~N}_{3} \mathrm{Br}$ & $138-140$ & 66.4 & 0.77 \\
\hline $\mathrm{Ic}$ & $4-\mathrm{C}_{2} \mathrm{H}_{5}$ & $\mathrm{C}_{25} \mathrm{H}_{20} \mathrm{~N}_{3} \mathrm{O}$ & $140-144$ & 61.1 & 0.63 \\
\hline $\mathrm{Id}$ & $2,4-$ dinitro & $\mathrm{C}_{25} \mathrm{H}_{15} \mathrm{~N}_{5} \mathrm{O}_{4}$ & $146-148$ & 81.3 & 0.70 \\
\hline $\mathrm{Ie}$ & $\mathrm{N}, \mathrm{N}-$ dimethyl & $\mathrm{C}_{24} \mathrm{H}_{22} \mathrm{~N}_{3}$ & $140-142$ & 72.9 & 0.62 \\
\hline
\end{tabular}

The physiochemical result of compounds IIFa-e were shown as

Table 3: Physicochemical data of compounds (IIFa-e)

\begin{tabular}{|c|c|c|c|c|c|}
\hline $\begin{array}{c}\text { Comp. } \\
\text { no. }\end{array}$ & $\mathbf{R}$ & $\begin{array}{c}\text { Molecular } \\
\text { Formula }\end{array}$ & $\mathbf{M . P}^{\circ} \mathrm{C}$ & $\begin{array}{c}\% \\
\text { Yield }\end{array}$ & $\begin{array}{c}\mathbf{R}_{\boldsymbol{f}} \\
\text { Value }\end{array}$ \\
\hline IIFa & $\mathrm{P}-\mathrm{NO}_{2}$ & $\mathrm{C}_{24} \mathrm{H}_{16} \mathrm{~N}_{4} \mathrm{O}_{3}$ & $72-74$ & 55.43 & 0.70 \\
\hline $\mathrm{IIFb}$ & $\mathrm{P}-\mathrm{Br}$ & $\mathrm{C}_{24} \mathrm{H}_{16} \mathrm{~N}_{3} \mathrm{OBr}$ & $66-70$ & 87.41 & 0.88 \\
\hline IIFc & $4-\mathrm{C}_{2} \mathrm{H}_{5}$ & $\mathrm{C}_{26} \mathrm{H}_{21} \mathrm{~N}_{3} \mathrm{O}$ & $70-72$ & 63.88 & 0.79 \\
\hline IIFd & $2,4-$ dinitro & $\mathrm{C}_{24} \mathrm{H}_{15} \mathrm{~N}_{5} \mathrm{O}_{5}$ & $78-80$ & 65.60 & 0.73 \\
\hline IIFe & N,N-dimethyl & $\mathrm{C}_{26} \mathrm{H}_{22} \mathrm{~N}_{3} \mathrm{O}$ & $68-70$ & 79.42 & 0.76 \\
\hline
\end{tabular}

\section{Antimicrobial Activity}

\section{a. Antibacterial activity ${ }^{13,14}$}

The antibacterial activities of compounds were screened against microorganism by disc diffusion method using standard Ampicillin (10mg/1ml of DMSO). Bacillus substilis and Staphylococcus aureus were used as representative of gram positive bacteria. In case of gram positive species Bacillus substilis, compound IIFd showed high activity. Compounds IIFa and IIFb showed moderate activity against Bacillus substilis. Compound IIFe showed slightly active while compound IIFc showed inactive against Bacillus substilis.For the species of Staphylococcus aureus compound IIFd showed high activity. Compounds IIFa, IIFc and IIFe showed moderate activity against Staphylococcus aureus. CompoundsIIFb showed slightly activity against Staphylococcus aureus.

\section{Gram Negative Species:}

Escherichia coli, Salmonella typhi were used as representative of gram negative bacteria. In case of gram negative species Escherichia coli, compound IIFd and IIFe showed high activity. Compounds IIFa and IIFb showed moderate activity against Escherichia coli. While other compounds IIFc are inactive against 
Escherichia coli. For the species Salmonella typhi compounds IIFd and IIFe showed high activity. Compounds $\mathrm{IIFb}$ and IIFC showed moderate activity. The remaining compound IIFa are inactive against Salmonellatyphi.

Table 4: Antibacterial screening results of synthesized compounds measuring the zone of inhibition in millimeters

\begin{tabular}{|c|c|c|c|c|c|}
\hline \multirow{2}{*}{ Sr. no. } & \multirow{2}{*}{ Comp. No. } & \multicolumn{5}{|c|}{ Name of organisms } \\
\cline { 3 - 6 } & & $E$. coli & S. aureus & B. substilis & S. typhi \\
\hline 1 & IIFa & ++ & ++ & ++ & - \\
\hline 2 & IIFb & ++ & + & ++ & ++ \\
\hline 3 & IIFc & - & ++ & - & ++ \\
\hline 4 & IIFd & - & +++ & +++ & +++ \\
\hline 5 & IIFe & +++ & ++ & + & +++ \\
\hline Standard & Ampicillin & +++ & ++ & ++ & +++ \\
\hline
\end{tabular}

Standard: Ampicillin (10mg/1ml of DMSO.)

Where,

Highly active $=+++($ inhibition zone $>9 \mathrm{~mm})$

Moderately active $=++($ inhibition zone $6-8 \mathrm{~mm})$

Slightly active $=+($ inhibition zone $3-5 \mathrm{~mm})$

Inactive $=-($ inhibition zone $<3 \mathrm{~mm})$

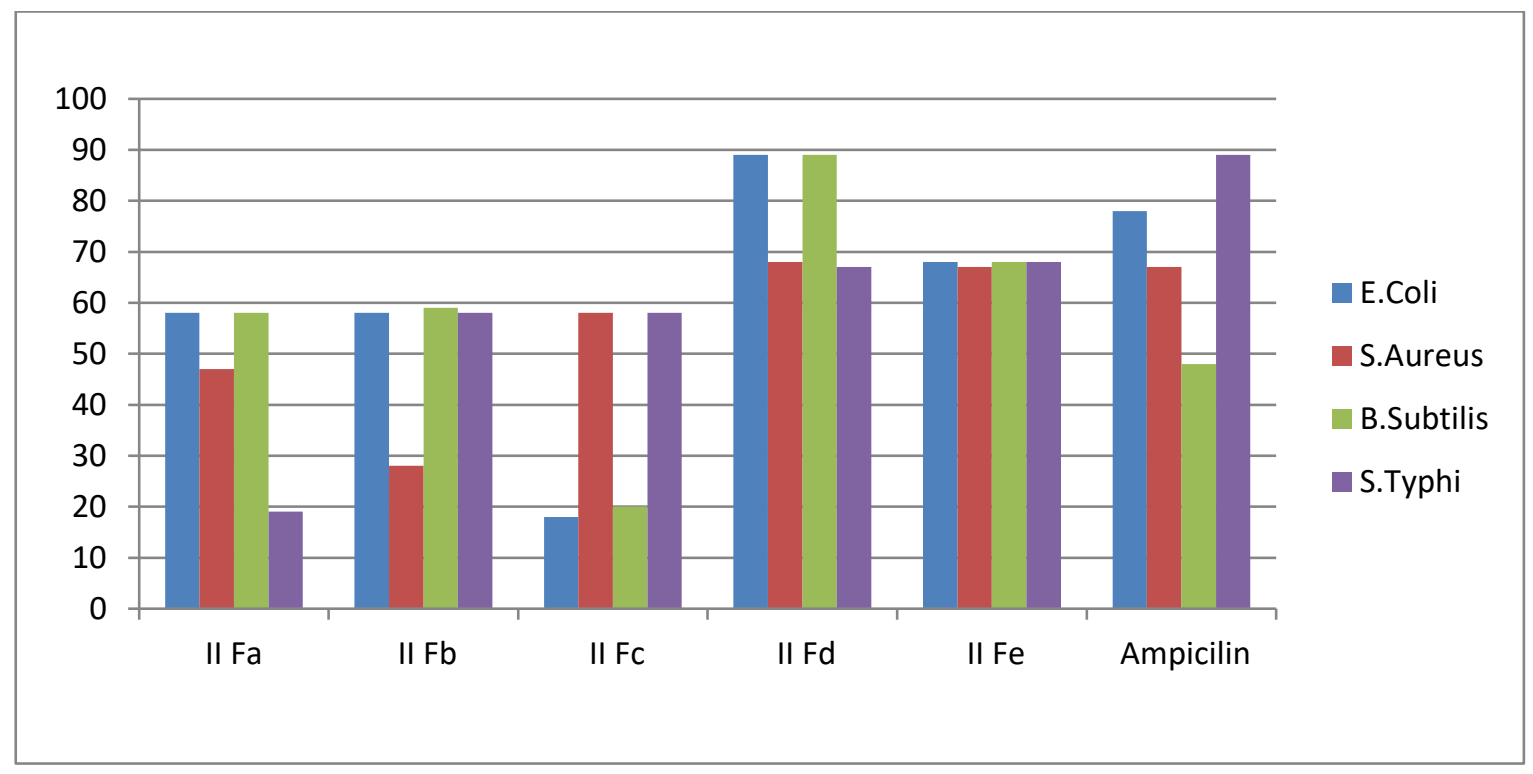

Fig1: Antimicrobial activity of Pyrrole Derivatives

\section{b. Antifungal activity}

The antifungal activities of compounds were screened against fungal species Candida albicans by disc-diffusion method using standard Fluconazole $(10 \mathrm{mg} / 1 \mathrm{ml}$ of DMSO). Candida albicans was used as representative of gram positive fungi. In case of gram positive species Candida albicans, compound IIFd showed high activity. 
Compounds IIFb and IIFc showed moderate activity against Candida albicans. Compound IIFe showed slightly active.Aspergillus niger was used as representative of gram negative fungi. In case of gram negative species Aspergillus niger, compound IIFe showed high activity. Compounds IIFa showed moderate activity against Aspergillus niger. Compound IIAc and IIFb and IIFd showed slightly active while compound IIFc showed inactive against Aspergillus niger.

Table 5: Antifungal screening results of synthesized compounds measuring the zone of inhibition in millimeters

\begin{tabular}{|c|c|c|c|c|c|c|c|}
\hline $\begin{array}{c}\text { Name of } \\
\text { Organism }\end{array}$ & IIFa & IIFb & IIFc & IIFd & IIFe & $\begin{array}{c}\text { Control } \\
\text { (DMSO) }\end{array}$ & Standard \\
\hline $\begin{array}{c}\text { Candida } \\
\text { albicans }\end{array}$ & + & ++ & + & ++ & - & - & ++ \\
\hline $\begin{array}{c}\text { Aspergilus } \\
\text { niger }\end{array}$ & + & - & - & - & ++ & - & + \\
\hline
\end{tabular}

Standard: Fluconazole $(10 \mathrm{mg} / 1 \mathrm{ml}$ of DMSO)

Where,

Highly active $=+++$ (inhibition zone $>10 \mathrm{~mm}$ )

Moderately active $=++($ inhibition zone 7-9 $\mathrm{mm}$ )

Slightly active $=+($ inhibition zone $4-6 \mathrm{~mm})$

Inactive $=-($ inhibition zone $<3 \mathrm{~mm})$

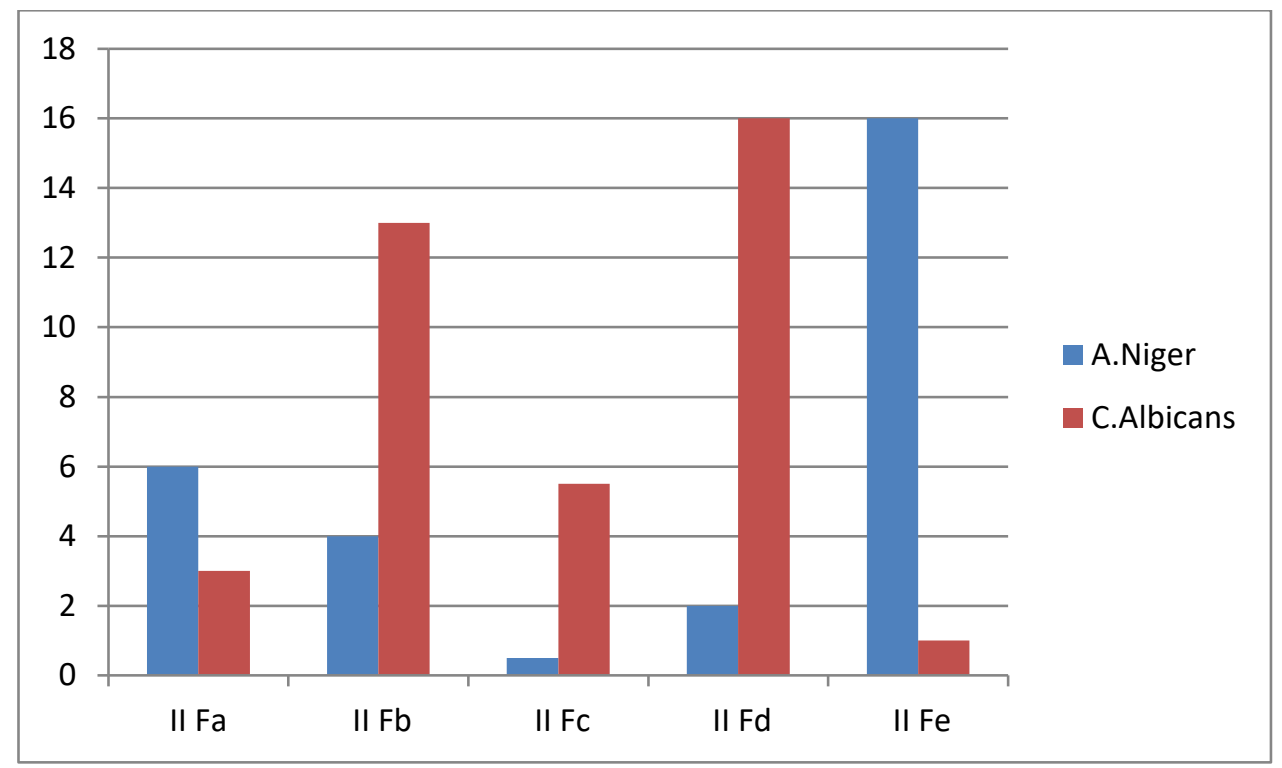

Fig. 2: Antifungal activity of Pyrrole Derivatives

\section{IV.CONCLUSION}

All the synthesized derivatives of novel series were synthesized by microwave method. Synthesis of compounds by the microwave method gives more yield and requires less time to complete the reaction. So, the microwave synthesis better method. All derivatives were prepared using method and they show promising physiochemical characteristics. The 
structural characterization of the synthesized compounds was done by the interpretation of IR, $1 \mathrm{H}$ NMR and MASS spectra. The entire compound showed satisfactory IR, 1H NMR and MASS data. In case of gram positive species Bacillus substilis, compound IIFd showed high activity. For the species of Staphylococcus aureus compound IIFd showed high activity. In case of gram negative species Escherichia coli, compound IIFd and IIFe showed high activity. For the species Salmonella typhi compounds IIFd and IIFe showed high activity. Compounds IIFd showed high activity against Candida albicans. compound IIFe showed high activity against Aspergillus niger.

\section{REFERENCES}

[1]. Elvis A. Somani R. Drug Designing, Discovery and Development Techniques. Promising Pharmaceuticals. 2012; 2(8): 2-36.

[2]. Frank K. Signaigo and Homer Adkins, The Reactions of Hydrogen with Derivatives of Pyrrole, J. Am. Chem. Soc. 1936; 58(5): 709716.

[3]. Mosaad Sayed Mohamed1 Ramdan Ahmed ElDomany2 Rania Helmy Abd El-Hameed, Synthesis of Certain Pyrrole Derivatives as Antimicro-Bial Agents, Acta Pharm. 2009; 59: 145-158.

[4]. Idhayadhulla A, Kumar R, Manilal A. Synthesis of some new pyrrole derivatives and their antimicrobial activity, Scholars Research Library. 2011; 3(4): 210-218.

[5]. Khulpe P, Mohite S. Synthesis and Characterization of 5,6-Diphenyl Pyrrole Derivatives and it's Pharmacological Profile. J Curr Pharma Res. 2014; 4(3): 1181-1185.

[6]. Kano P, Burapapadh K. Characterization of recrystallized itraconazole prepared by cooling and anti-solvent crystallization. Asian J Pharm Sci. 2015; 10(3): 230-238.
[7]. Abedawn I. Khalaf, Judith K. Huggan, Colin J. Suckling, Colin L. Gibson, Kirsten Stewart, Federica Giordani, Michael P. Barrett, Pui Ee Wong, Keri L. Barrack, William N. Hunter, Structure-Based Design and Synthesis of Antiparasitic Pyrrolopyrimidines Targeting Pteridine Reductase, J. Med. Chem. 2014; 57(15): 6479-6494.

[8]. Karrouchi K, Radi S, Ramli Y, Taoufik J, Mabkhot Y, Faiz A. Al-aizari, M'hammed Ansar, Khalid Karrouchi, Smaail Radi, Youssef Ramli, Jamal Taoufik, Yahia N. Mabkhot, Faiz A. Al-aizari, M'hammed Ansar, Synthesis and Pharmacological Activities of Pyrazole Derivatives: A Review, Molecules 2018; 23(134): 1-85.

[9]. Pikun N, Sobolev A, Plotniece A, Martins Rucins, Brigita Vigante, Marina Petrova, Ruslan Muhamadejev, Karlis Pajuste, Yuriy G. Shermolovich, Synthesis of Fluorinated 3,6Dihydropyridines and 2(Fluoromethyl)pyridines by Electrophilic Fluorination of 1,2-Dihydropyridines with Selectfluor, Molecules. 2020; 25(14): 3143

[10]. Kapil S. Pandit, Ravindra V. Kupwade, Pramod V. Chavan, Uday V. Desai, Prakash P. Wadgaonkar, Kisan M. Kodam, Problem Solving and Environmentally Benign Approach toward Diversity Oriented Synthesis of Novel 2-Amino-3-phenyl (or Alkyl) Sulfonyl-4Hchromenes at Ambient Temperature, ACS Sustainable Chem. Eng. 2016; 4(6): 3450-3464.

[11]. Sarita Manandhar, Shisir Luitel, Raj Kumar Dahal, In Vitro Antimicrobial Activity of Some Medicinal Plants against Human Pathogenic Bacteria, Journal of Tropical Medicine, 2019; 15.

[12]. Ayman Al-Mariri, Mazen Safi, In Vitro Antibacterial Activity of Several Plant Extracts and Oils against Some Gram-Negative Bacteria, Iran J Med Sci., 2014; 39(1): 36-43. 
[13]. Gislene G. F. Nascimento, Juliana Locatelli, Paulo C. Freitas, Giuliana L. Silva, Antibacterial Activity of Plant Extracts and Phytochemicals on Antibiotic-Resistant Bacteria, Braz. J. Microbiol, 2000; 31(4): 1-10.

[14]. Yucheng Cao, Jingxuan Ni, Wentao Ji, Kangle Shang, Kaicheng Liang, Jing Lu, Yi Bi, Xiaomin Luo, Synthesis, antifungal activity and potential mechanism of fusidic acid derivatives possessing amino-terminal groups, Future Medicinal Chemistry, 2020; 12(9): 1-12.

[15]. Yadav A, Mohite S. A Brief Review: Microwave Chemistry and its Applications. Res. J. Pharma. Dosage Forms and Tech. 2020; 12(3): 191-197.

[16]. Yadav A, Mohite S. Recent Advances in the Ultrasound-Assisted Synthesis of Oxadiazole and Thiazole Derivatives. Res. J. Pharma. Dosage Forms and Tech. 2020; 12(4): 225-228.

[17]. Yadav A, Mohite S. Carbon Nanotubes as an Effective Solution for Cancer Therapy. Res. J. Pharma. Dosage Forms and Tech. 2020; 12(4): 238-241.

[18]. Yadav A, Mohite S. Different Techniques and Characterization of Polymorphism with their Evaluation: A Review. Asian J. Pharm. Tech. 2020; 10(3): 213-216.

[19]. Yadav A, Mohite S. Anthelmintic and Antibacterial Activity of Psidium Guajava Leaf Extracts. Int J Sci Res Chemi. 2020; 5(6): 06-11.

[20]. Yadav A, Honmane P, Bhosale M, Chitruk A, Rode P, Birajdar R, Rajput M, Suryawanshi V, Patil S, Patil, Jagtap N, Mohite S, Dange V, Vambhurkar G. Antifungal Activity of Malvastrum Coromandelianum Leaf Extracts. Int J Sci Res Chemi. 2020; 5(6): 01-05.

[21]. Yadav A, Mohite S. Screening of In-vitro antiinflammatory and Antifungal assay of Psidium guajava Leaf Extracts. Research J. Topical and Cosmetic Sci. 2020; 11(2): 62-64.

[22]. Yadav A, Mohite S. Rajput M, Suryawanshi V, Birajdar R, Patil M. Antioxidant Activity of
Psidium guajava Leaf Extracts. Res. J. Pharma. Dosage Forms and Tech. 2020; 12(3): 159-161.

[23]. Yadav A, Mohite S. Photochemistry and Spectroscopy. Int J Sci Res Chemi. 5(5): 71-76.

[24]. Yadav A. Transition-metal and Organocatalysis in Organic Synthesis: Metal-catalyzed Reactions. International Journal of Pharmacy and Pharmaceutical Science. 2020; 2(1): 06-09.

[25]. Yadav A. Role of Medicinal Chemistry in the Current Scenario. International Journal of Pharmacy and Pharmaceutical Science. 2020; 2(1): 27-36.

[26]. Yadav A. Analog Design as Useful Strategy for Molecular Modification and Drug Design. Res. J. Pharma. Dosage Forms and Tech. 2021; 13(2): 134-8.

[27]. Yadav A, Mohite S, Magdum C. Comparative Study of Conventional and Microwave Assisted Synthesis of some Organic Reactions. Asian J. Pharm. Res. 2020; 10(3): 217-220.

[28]. Yadav A, Mohite S. Green Chemistry approach for Microwave assisted synthesis of some Traditional Reactions. Asian J. Research Chem. 2020; 13(4): 261-264.

[29]. Yadav A, Gavali K, Rajput M, Pathade K, Patil S, Dharanguttikar V, Mohite S. Anthelmintic Activity of Malvastrum Coromandelianum Leaf Extracts against Pheretima Posthuma and Ascardia Galli. Int J Sci Res Chemi. 2020; 5(6): 18-24.

[30]. Yadav A, Rajput M, Gavali K, Pathade K, Honmane P, Mohite S. Anthelmintic and Antibacterial Activity of Psidium Guajava Leaf Extracts. Int J Sci Res Chemi. 2020; 5(6): 6-11.

[31]. Yadav A, Mohite S. Toxicological Evaluation of Eclipta alba using Brine Shrimp (Artemia salina L.) Model. Int J Sci Res Chemi. 2020; 5(6): 5662.

[32]. Yadav A, Mohite S. In vitro Studies on the Inhibition of $\alpha$-amylase and $\alpha$-glucosidase by Methanolic Extract of Barleria Prionitis L. and 
Psidium guajava. Int J Sci Res Chemi. 2020; 5(1): 50-58.

[33]. Yadav A, Honamane P, Rajput M, Dange V, Salunkhe K, Kane S, Mohite S. Antimalarial Activity of Psidium guajava Leaf Extracts. Int J Sci Res Chemi. 2020; 5(6): 63-68.

[34]. Yadav A, Mohite S. Anticancer Activity and InSilico ADMET Analysis of Malvastrum Coromandelianum. International Journal of Pharma Sciences and Research. 2020; 11(5): 7173.

[35]. Yadav A, Mohite S. Toxicological Evaluation of Psidium guajava Leaf Extracts using Brine Shrimp (Artemia salina L.) Model. Res. J. Pharma. Dosage Forms and Tech. 2020; 12(4): 198-120.

[36]. Suryawanshi V, Yadav A, Mohite S. Toxicological Assessment using Brine Shrimp Lethality Assay and Antimicrobial activity of Capparis Grandis. Journal of University of Shanghai for Science and Technology. 2020; 22(11): 746-759.

[37]. Pawara N, Yadav A, Mohite S. Pharmacognostic, Phytochemical Investigation and Antioxidant Potential of Embelia ribes. Int J Sci Res Chemi. 5(6): 27-34.

[38]. Yadav A, Rajput M, Gavali K, Mohite S. Invitro Hypoglycemic Activity of Barleria prionitis L. Int J Sci Res Chemi. 2020; 5(5): 6370.

[39]. Yadav A, Mohite S. Screening of In-vitro antiinflammatory and Antibacterial assay of Malvastrum Coromandelianum. International Journal of Pharma Sciences and Research. 2020; 11(4): 68-70.

[40]. Birajdar R, Yadav A, Patil S, Chitruk A, Kane S, Mohite S, Magdum C. Pharmacognostic and Phytochemical Investigation, Molecular Docking Studies of Phytoconstituents and Anticancer Potential of Capparis Decidua (Forsk) Edgew. Journal of University of
Shanghai for Science and Technology. 2020; 22(11): 500-519.

[41]. Gavali K, Yadav A, Howal R, Tamboli A. Preliminary Phytochemical Screening and HPTLC Finger printing of Leaf Extracts of Tectona grandis Linn Journal of University of Shanghai for Science and Technology. 2020; 22(11): 1804-1815.

[42]. Yadav A, Mohite S. ADME analysis of phytochemical constituents of Psidium guajava. Asian J. Res. Chem. 2020; 13(5): 373-375.

[43]. Yadav A, Mohite S. LC50 Determination of Barleria Prionitis L. by Brine Shrimp Lethality Assay. Int J Sci Res Chemi. 2020; 5(2): 26-32.

[44]. Yadav A, Mohite S. Anticancer Activity of Psidium guajava Leaf Extracts on Breast Cancer Cell Line. Res. J. Pharma. Dosage Forms and Tech. 2020; 12(4): 298-300.

[45]. Yadav A. In-vitro Studies on the Inhibition of $\alpha$-amylase and $\alpha$-glucosidase by Methanolic Extract of Lawsonia inermis and Malvastrum coromandelianum. International Journal of Pharmacognosy and Pharmaceutical Research. 2020; 2(1): 09-12.

[46]. Yadav A. Assessment of Bioactivity of Lawsonia inermis Linn. using Brine Shrimp (Artemia salina) Lethality Assay. International Journal of Pharmacognosy and Pharmaceutical Research. 2020; 2(1): 13-16.

[47]. Yadav A. In-vitro Hypoglycemic Activity of Lawsonia inermis Linn. Leaf Extracts. International Journal of Pharmacognosy and Pharmaceutical Sciences. 2021; 3(1): 01-04.

[48]. Yadav A, Dange V, Mohite S. Pathogensis of Cell Injury. Int J Sci Res Chemi. 2020; 5(6): 1218.

[49]. Yadav A, Mohite S. A Novel approach for treatment of COVID-19 with Convalescent Plasma. Res. J. Pharma. Dosage Forms and Tech. 2020; 12(3): 227-230.

[50]. Yadav A, Mohite S. A Review on Novel Coronavirus (COVID-19). International Journal 
of Pharma Sciences and Research. 2020; 11(5): 74-76.

[51]. Yadav A, Mohite S. Role of Indian Youth in Keeping COVID-19 at Bay. International Journal of Scientific Research in Chemistry. 2020; 5(5): 46-50.

[52]. Yadav A, Mohite S. A Review on severe acute respiratory infection (SARI) and its clinical management in suspect/confirmed novel coronavirus (nCoV) cases Res. J. Pharma. Dosage Forms and Tech. 2020; 12(3): 178-180.

[53]. Yadav A, Mohite S. Pharmacophore Mapping and Virtual Screening. Int J Sci Res Chemi. 5(5): 77-80.

[54]. Yadav A, Mohite S. QSAR Studies as Strategic Approach in Drug Discovery. Int J Sci Res Chemi. 2019; 4(6): 16-22.

[55]. Yadav A, Mohite S. Prediction and Optimization of Drug Metabolism and Pharmacokinetics Properties Including Absorption, Distribution, Metabolism, Excretion, and the Potential for Toxicity Properties. Int J Sci Res Chemi. 2020; 4(5): 4758.

[56]. Yadav A, Mohite S. Homology Modeling and Generation of 3D-structure of Protein. Res. J. Pharma. Dosage Forms and Tech. 2020; 12(4): 313-320.

[57]. Yadav A, Mohite S. A Review on Zika Virus Infection. Res. J. Pharma. Dosage Forms and Tech. 2020; 12(4): 245-249.

[58]. Yadav A, Mohite S. An Overview on Ebola Virus Disease. Res. J. Pharma. Dosage Forms and Tech.2020; 12(4): 230-235.

[59]. Yadav A, Mohite S. Cancer- A Silent Killer: An Overview. Asian J. Pharm. Res. 2020; 10(3): 213-216.

[60]. Yadav A, Dange V. Biochemical Mediators of Inflammation and Basic Principles of Wound Healing in the Skin. International Journal of Pharmacology and Pharmaceutical Sciences. 2020; 2(1): 14-18.
[61]. Yadav A, Dange V. Mechanism Involved in the Process of Inflammation. International Journal of Pharmacology and Pharmaceutical Sciences. 2020; 2(1): 01-06.

[62]. Yadav A, CPCSEA Guidelines for Laboratory Animal Facility. International Journal of Pharmacology and Pharmaceutical Sciences. 2020; 2(1): 09-13.

[63]. Yadav A, Mohite S, Magdum C. Microwave assisted synthesis of some Traditional reactions: Green chemistry approach. Asian J. Research Chem. 2020; 13(4): 275-278.

[64]. Yadav A, Mohite S, Magdum C, Synthesis, Characterization and Biological Evaluation of Some Novel 1,3,4-Oxadiazole Derivatives as Potential Anticancer Agents, Int J Sci Res Sci Technol. 2020; 7(2) : 275-282.

[65]. Rode P, Yadav A, Chitruk A, Mohite S, Magdum C. Synthesis, Anticancer and Molecular Docking Studies of $\mathrm{N}-(1 \mathrm{H}-$ benzimidazol-2-yl-carbamothioyl)benzamide Analogues. Int. j. sci. res. sci. technol. 2020; 5(6): 204-212.

[66]. Honmane P, Yadav A, Singh S, Mohite S. Synthesis, Characterization and Antiplatelet Activity of Antithrombotic novel 2,5substituted aryl-7-phenyl-1,3,4-oxadiazolo[3,2-a]-1,3,5-triazine Derivatives. Journal of University of Shanghai for Science and Technology. 2020; 22(11): 881-898.

[67]. Honmane P, Yadav A, Singh S, Mohite S. Synthesis of Pyrazole Acrylic acid based Oxadiazole and Amide Derivatives as Larvicidal and Antitubercular agents. Seybold Rep. 2020; 25(10): 516-530.

[68]. Rajput M. D, Yadav A. R, Mohite S. K. Synthesis, Characterization of Benzimidazole Derivatives as Potent Antimicrobial Agents. International Journal of Pharmacy \& Pharmaceutical Research. 2020; 17(4): 279-285.

[69]. Pathade K, Mohite S, Yadav A. Synthesis, Molecular Docking Studies of Novel 4- 
(Substituted Ph Phenyl Amino)-6-(Substituted Aniline)-N'-Aryl-1,3,5-Triazine-2-

Carbahydrazide Derivatives As Potent Antitubercular Agents. Journal of University of Shanghai for Science and Technology. 2020; 22(11): 1891-1909.

[70]. Yadav A, Mohite S. A Review on Zika Virus Infection. Res. J. Pharma. Dosage Forms and Tech. 2020; 12(4): 245-249.

[71]. Yadav A, Mohite S. An Overview on Ebola Virus Disease. Res. J. Pharma. Dosage Forms and Tech.2020; 12(4): 230-235.

[72]. Yadav A, Mohite S. Cancer- A Silent Killer: An Overview. Asian J. Pharm. Res. 2020; 10(3): 213-216.

[73]. Yadav A, Dange V. Biochemical Mediators of Inflammation and Basic Principles of Wound Healing in the Skin. International Journal of Pharmacology and Pharmaceutical Sciences. 2020; 2(1): 14-18.

[74]. Yadav A, Dange V. Mechanism Involved in the Process of Inflammation. International Journal of Pharmacology and Pharmaceutical Sciences. 2020; 2(1): 01-06.

[75]. Bhosale M, Yadav A, Magdum C, Mohite S. Synthesis, molecular docking studies and biological evaluation of 1,3,4-thiadiazole derivatives as antimicrobial agents. Int. J. Curr. Adv. Res. 2020; 09(08)(A): 22894-22899.

[76]. Chitruk A, Yadav A, Rode P, Mohite S, Magdum C. Microwave assisted synthesis, antimicrobial and anti-inflammatory potential of some novel 1,2,4-triazole derivatives. Int. j. sci. res. sci. technol. 2020; 7(4): 360-367.

[77]. Honmane P, Yadav A, Singh S, Mohite S. Microwave Assisted Synthesis of Novel Benzimidazole Derivatives as Potent Antileishmanial and Antimalarial Agents. Int. J. Curr. Adv. Res. 2020; 09(07)(B): 22742-22746.

[78]. Yadav A, Mohite S. Design, synthesis and characterization of some novel benzamide derivatives and it's pharmacological screening. Int. j. sci. res. sci. technol. 2020; 7(2), 68-74.

[79]. Yadav A, Mohite S. Production of Statins by Fungal Fermentation. Int J Sci Res Chemi. 2020; 5(1): 59-64.

[80]. Chitruk A, Yadav A Rode P, Mohite S, Magdum C. Microwave assisted synthesis, antimicrobial and anti-inflammatory potential of some novel 1,2,4-triazole derivatives. Int. j. sci. res. sci. technol. 2020; 7(4): 360-367.

[81]. Yadav A, Mohite S. Screening of In-vitro antiinflammatory and Antifungal assay of Psidium guajava Leaf Extracts. Research J. Topical and Cosmetic Sci. 2020; 11(2): 62-64.

[82]. Yadav A, Mohite S. Rajput M, Suryawanshi V, Birajdar R, Patil M. Antioxidant Activity of Psidium guajava Leaf Extracts. Res. J. Pharma. Dosage Forms and Tech. 2020; 12(3): 159-161.

[83]. Yadav A, Gavali K, Rajput M, Pathade K, Patil S, Dharanguttikar V, Mohite S. Anthelmintic Activity of Malvastrum Coromandelianum Leaf Extracts against Pheretima Posthuma and Ascardia Galli. Int J Sci Res Chemi. 2020; 5(6): 18-24.

[84]. Yadav A, Rajput M, Gavali K, Pathade K, Honmane $\mathrm{P}$, Mohite S. Anthelmintic and Antibacterial Activity of Psidium Guajava Leaf Extracts. Int J Sci Res Chemi. 2020; 5(6): 6-11.

[85]. Yadav A, Mohite S. Toxicological Evaluation of Eclipta alba using Brine Shrimp (Artemia salina L.) Model. Int J Sci Res Chemi. 2020; 5(6): 5662.

[86]. Yadav A, Mohite S. In vitro Studies on the Inhibition of $\alpha$-amylase and $\alpha$-glucosidase by Methanolic Extract of Barleria Prionitis L. and Psidium guajava. Int J Sci Res Chemi. 2020; 5(1): 50-58.

[87]. Yadav A, Honamane P, Rajput M, Dange V, Salunkhe K, Kane S, Mohite S. Antimalarial Activity of Psidium guajava Leaf Extracts. Int J Sci Res Chemi. 2020; 5(6): 63-68. 
[88]. Yadav A, Mohite S. Anticancer Activity and InSilico ADMET Analysis of Malvastrum Coromandelianum. International Journal of Pharma Sciences and Research. 2020; 11(5): 7173.

[89]. Yadav A, Mohite S. Toxicological Evaluation of Psidium guajava Leaf Extracts using Brine Shrimp (Artemia salina L.) Model. Res. J. Pharma. Dosage Forms and Tech. 2020; 12(4): 198-120.

[90]. Suryawanshi V, Yadav A, Mohite S. Toxicological Assessment using Brine Shrimp Lethality Assay and Antimicrobial activity of Capparis Grandis. Journal of University of Shanghai for Science and Technology. 2020; 22(11): 746-759.

[91]. Pawara N, Yadav A, Mohite S. Pharmacognostic, Phytochemical Investigation and Antioxidant Potential of Embelia ribes. Int J Sci Res Chemi. 5(6): 27-34.

[92]. Yadav A, Rajput M, Gavali K, Mohite S. Invitro Hypoglycemic Activity of Barleria prionitis L. Int J Sci Res Chemi. 2020; 5(5): 6370.

[93]. Yadav A, Mohite S. Screening of In-vitro antiinflammatory and Antibacterial assay of Malvastrum Coromandelianum. International Journal of Pharma Sciences and Research. 2020; 11(4): 68-70.

[94]. Birajdar R, Yadav A, Patil S, Chitruk A, Kane S, Mohite S, Magdum C. Pharmacognostic and Phytochemical Investigation, Molecular Docking Studies of Phytoconstituents and Anticancer Potential of Capparis Decidua (Forsk) Edgew. Journal of University of Shanghai for Science and Technology. 2020; 22(11): 500-519.

[95]. Gavali K, Yadav A, Howal R, Tamboli A. Preliminary Phytochemical Screening and HPTLC Finger printing of Leaf Extracts of Tectona grandis Linn Journal of University of
Shanghai for Science and Technology. 2020; 22(11): 1804-1815.

[96]. Yadav A, Mohite S. ADME analysis of phytochemical constituents of Psidium guajava. Asian J. Res. Chem. 2020; 13(5): 373-375.

[97]. Yadav A, Mohite S. LC50 Determination of Barleria Prionitis L. by Brine Shrimp Lethality Assay. International Journal of Scientific Research in Chemistry. 2020; 5(2): 26-32.

[98]. Yadav A, Mohite S. Anticancer Activity of Psidium guajava Leaf Extracts on Breast Cancer Cell Line. Research Journal of Pharmaceutical Dosage forms and Technology. 2020; 12(4): 298-300.

[99]. Yadav A. In-vitro Studies on the Inhibition of $\alpha$-amylase and $\alpha$-glucosidase by Methanolic Extract of Lawsonia inermis and Malvastrum coromandelianum. International Journal of Pharmacognosy and Pharmaceutical Research. 2020; 2(1): 09-12.

[100]. Yadav A. Assessment of Bioactivity of Lawsonia inermis Linn. using Brine Shrimp (Artemia salina) Lethality Assay. International Journal of Pharmacognosy and Pharmaceutical Research. 2020; 2(1): 13-16.

[101]. Yadav A. In-vitro Hypoglycemic Activity of Lawsonia inermis Linn. Leaf Extracts. International Journal of Pharmacognosy and Pharmaceutical Sciences. 2021; 3(1): 01-04.

[102]. Yadav A, Mohite S. Pharmacophore Mapping and Virtual Screening. Int J Sci Res Chemi. 5(5): 77-80.

[103]. Yadav A, Mohite S. QSAR Studies as Strategic Approach in Drug Discovery. Int J Sci Res Chemi. 2019; 4(6): 16-22.

[104]. Yadav A, Mohite S. Prediction and Optimization of Drug Metabolism and Pharmacokinetics Properties Including Absorption, Distribution, Metabolism, Excretion, and the Potential for Toxicity Properties. Int J Sci Res Chemi. 2020; 4(5): 4758. 
[105]. Yadav A, Mohite S. Homology Modeling and Generation of 3D-structure of Protein. Research Journal of Pharmaceutical Dosage forms and Technology. 2020; 12(4): 313-320.

[106]. Pathade K, Mohite S, Yadav A. 3D-QSAR And ADMET Prediction Of Triazine Derivatives For Designing Potent Anticancer Agents. Journal of University of Shanghai for Science and Technology. 2020; 22(11): 1816-1833.

[107]. Bhosale M, Yadav A, Magdum C, Mohite S. Molecular Docking Studies, Synthesis, Toxicological Evaluation using Brine Shrimp (Artemia salina L.) Model and Antiinflammatory Activity of Some N-(substituted)5-phenyl-1,3,4-thiadiazol-2-amine Derivatives. Int J Sci Res Sci \& Technol. 2020; 7(5): 51-62.

[108]. Bhosale M, Yadav A, Magdum C, Mohite S. Microwave Assisted Synthesis, Molecular Docking Studies and Anticancer Screening of Some 1,3,4-thiadiazole Derivatives. Journal of University of Shanghai for Science and Technology. 2020; 22(11):520-534.

[109]. Rode P, Yadav A, Chitruk A, Mohite S, Magdum C. Microwave assisted synthesis, toxicological assessment using brine shrimp lethality assay and antimicrobial potential of new series of benzimidazole derivatives. Int. J. Curr. Adv. Res. 2020; 09(08)(A): 22900-22905.

[110]. Yadav A, Mohite S. Molecular Properties Prediction and Synthesis of Novel Benzimidazole Analogues as Potent Antimicrobial agents. Int J Sci Res Chemi. 2019; 4(6): 23-34.

[111]. Rajput M, Yadav A. Green Chemistry Approach for Synthesis of Some 1,3,4-Oxadiazole Derivatives As Potent Antimalarial Agents Journal of University of Shanghai for Science and Technology. 2020; 22(11): 1854-1869.

[112]. Yadav A, Mohite S. In-Silico ADME Analysis of 1, 3, 4-oxadiazole derivatives as CDK9 Inhibitors. International Journal of Chemical Science. 2020; 4(3): 01-04.
[113]. Patil S, Yadav A, Birajdar R, Kane S, Mohite S, Magdum C. Microwave Assisted Synthesis, Molecular Docking Studies of new N-\{[5(phenyl)-1,3,4-thiadiazole-2-yl]carbamothioyl\} Derivatives as Potent Antimicrobial Agents. Journal of University of Shanghai for Science and Technology. 2020; 22(11): 1095-1113.

[114]. Yadav A, Mohite S. A Novel approach for treatment of COVID-19 with Convalescent Plasma. Res. J. Pharma. Dosage Forms and Tech. 2020; 12(3): 227-230.

[115]. Yadav A, Mohite S. A Review on Novel Coronavirus (COVID-19). International Journal of Pharma Sciences and Research. 2020; 11(5): 74-76.

[116]. Yadav A, Mohite S. Role of Indian Youth in Keeping COVID-19 at Bay. International Journal of Scientific Research in Chemistry. 2020; 5(5): 46-50.

[117]. Yadav A, Mohite S. A Review on severe acute respiratory infection (SARI) and its clinical management in suspect/confirmed novel coronavirus (nCoV) cases Res. J. Pharma. Dosage Forms and Tech. 2020; 12(3): 178-180.

[118]. Sankpal S, Pathade K, Yadav A. Synthesis and Characterization of Novel Imidazo(1,2a)pyrimidine Derivatives and their Evaluation for Antiepileptic and Analgesic activity. Journal of Shanghai Jiaotong University. 2020; 16(11): 404-422.

[119]. Salunkhe P, Yadav A. Synthesis, Molecular Docking Studies and In-Silico ADMET Screening of Some Novel N(phenylcarbamothioyl)benzamide Derivatives as Potential Anticancer Agents. Pensee. 2020; 51(2): 959-976.

[120]. Khade S, Yadav A. Synthesis, Characterization and Biological Evaluation of 2-phenyl-3(substituted benzo[d] thiazol-2-ylamino)quinazoline-4(3H)-one Derivatives endowed with potent Antitubercular, Antileishmanial 
and Larvacidal agents. Pensee. 2020; 51(2): 938958.

[121]. Yadav A. Recent Strategic Advances in Pharmaceutical Chemistry. Int J Sci Res Chemi. 2020; 6(1): 30-43.

[122]. Yadav A. Computational Evaluation by In-silico Pharmacokinetics and Drug-likeness Prediction of 1,4-naphthoquinones Derivatives with $[1,2,4]$-triazole-3-thione Substitution as Potent Insecticidal agents. Int J Sci Res Chemi. 2020; 6(1): 44-52.

[123]. Yadav A. Molecular Docking Study of Phytochemicals of Gymnema Sylvestre and Their Effects on the Complex of SARS-CoV2 Spike Protein and Human ACE2. Int J Sci Res Chemi. 2020; 6(1): 01-06.

[124]. Honmane P, Yadav A, Durgavale P, Desai M, Singh S, Doijad R, Mohite S. A Review on History, Pharmacological Potential of Medicinal active Antimycobacterial Azole Derivatives. Lino Journal. 2021; 11(4): 44-52.

\section{Cite this article as :}

Safiya R. Shaikh, Hanmant S. Mali, Shubhangi S. Thorat, Vishwajit D. Dhaygude, Muskan M. Bhaldarakar, Akshay R. Yadav, "Synthesis, Characterization and Biological Evaluation of Some Pyrrole Derivatives as Potential Antimicrobial Agents", International Journal of Scientific Research in Science and Technology(IJSRST), Print ISSN : 2395-6011, Online ISSN : 2395-602X, Volume 8, Issue 3, pp.757-770, May-June-2021. Available at doi: https://doi.org/10.32628/IJSRST2183150 Journal URL : https://ijsrst.com/IJSRST2183150 